\title{
GENOTOXIC IMPURITIES: AN IMPORTANT REGULATORY ASPECT
}

\author{
ANITA R POUNIKAR, MILIND J UMEKAR, KRISHNA R GUPTA*
}

Department of Pharmaceutical Chemistry, Smt. Kishoritai Bhoyar College of Pharmacy, New Kamptee, Nagpur, Maharashtra, India. Email: krg1903@gmail.com

Received: 07 March 2020, Revised and Accepted: 11 April 2020

ABSTRACT

Genotoxins are agents/carriers such as chemical or radiation that can cause the damage to DNA or chromosomal structure, thereby causing mutations and the process are called as genotoxicity. Identification and understanding of genotoxins at a primary stage of drug development would enable us to prevent the potential damage that can be caused by these genotoxic agents. Various regulatory agencies such as International Council for Harmonization and EMEA, USFDA, European Pharmacopeia guidance, guidance for oncology products provide guidelines to limits the level of impurities in drug substances and drug products. Nowadays, conventional protocol of isolation, various spectral analysis high-performance liquid chromatography (LC), Fourier transform infrared to on-line analysis using modern, sophisticated hyphenated tools, like gas chromatography-mass spectroscopy, LC-MS so on, as well as modern software based in silico drug designs are extensively used by industry, research, and development areas and also there is tremendous increase in publications in the literature involving their use. Our review article focused on the various regulatory guidelines, application of hyphenated tools, and in silico techniques in genotoxic impurity and degradation product profiling of small molecules. A brief explanation is made on possible pitfalls in the experimentation and data interpretation. From this review, it concluded that there are various countries having their own regulatory agencies and regulatory guidelines for drug approvals, which may be followed by applying new chemical entities the new drug application title (NDA) in new drug application as well as there are various conventional to modern software based techniques to quantification of genotoxic impurities.

Keywords: Genotoxicity, Sources, Guidelines, Techniques for quantification, Control strategy, Limitations of present regulatory system to test genotoxicity.

(C) 2020 The Authors. Published by Innovare Academic Sciences Pvt Ltd. This is an open access article under the CC BY license (http://creativecommons. org/licenses/by/4. 0/) DOI: http://dx.doi.org/10.22159/ajpcr.2020.v13i6.37370

\section{INTRODUCTION}

\section{Genotoxicity}

Genotoxicity is defined as destructive effect on genetic material (DNA, and RNA) of a cell and affects its integrity. Genotoxins are mutagens (radiation, chemical, or physical agents). A substance which shows genotoxicity is known as a genotoxin. Genotoxins can be carcinogens, or cancer-causing agents, mutagens, or mutation-causing agents, or teratogens, and birth defect-causing agents [1].

\section{Sources}

International Council for Harmonization (ICH), Food and Drug Administration (FDA), and USP defined impurities are classified into drug-related impurities, process-related impurities (PRIs), residual solvents, and heavy metals represented in Fig. 1. Two types of active pharmaceutical ingredients (API)-related impurities are further classified as the first type of API-related impurities due to reactions, for example, certain reactions, for example, oxidation, dehydration, and carbon dioxide removal. The other type is due to the interaction between API and excipients, container, or residual impurities in excipients, reagents, or solvents. API-related impurities are potentially genotoxic, mutagenic, and carcinogenic risk due to their structure activity relationship [2]

Genotoxic impurities can get incorporated through various sources, mostly starting material used in drug synthesis and its impurities in the form of genotoxic intermediate or process related by-products in the synthesis process. Furthermore, synthesis components such as solvents, catalyst, and reagent used in drug synthesis takes part as genotoxic impurities in drug substances. Drug degradation on storage, exposure to light, air oxidation, or hydrolysis results in generation of impurities in drug substances. Synthesis of stereoselective drug also may contain stereoisomers of raw material and intermediate also contribute to the generation of chiral impurities in drug substances. Fig. 2 shows the formation of impurities at different stages of drug synthesis (Table 1) [3].

\section{Need of genotoxicity determination}

Genotoxicity data help in risk assessment of chemicals as well as food and feed, consumer products, human and veterinary medicines, and industrial. Genotoxicity data are the basic for risk assessment of natural, environmental contaminants in chemicals, food, and feed. On this basis many regulatory agencies and advisory bodies have made recommendations on strategies for genotoxicity testing. Genetic alterations in genetic materials such as in somatic and germ cells affect serious health even at low exposure levels. Mutations in proto-oncogenes, tumor suppressor genes, or DNA damage response genes by various carriers such as physical, and chemical, responsible for a variety of genetic diseases. Somatic cells having damaged DNA also responsible for degenerative conditions such as accelerated aging, immune dysfunction, cardiovascular, and neurodegenerative diseases (flow chart displayed in Fig. 3). To prevent such adverse consequences of genetic damage to human health, the assessment of mutagenic potential is a basic component of chemical risk assessment [4].

Regulatory authorities all over the world require regulatory data on the genotoxic potential of new drugs, as documented evidence of safety evaluation of product and process. Therefore, pre-clinical studies are generally conducted to evaluate basic toxicological data of new chemical entities (NCE). On the basis of toxicological data, safety and efficacy of NCE and will help in analyzing and predicting whether the drug's likely have risk or benefit assessment in the new drug application (NDA) process as well as helps in identification with respect to genotoxicity hazardous for DNA damage and its fixation [5].

\section{GUIDELINES}

ICH and EMEA, USFDA, European Pharmacopoeia guidance, Guidance for oncology products, etc., provide guidelines to limits the level of impurities in drug substances and drug products [6-9].

\section{EMEA guideline}

EMEA guideline on the limits of genotoxic/mutagenic impurities (GTIs) [10], classifies GTIs into two categories. GTIs with experimental 


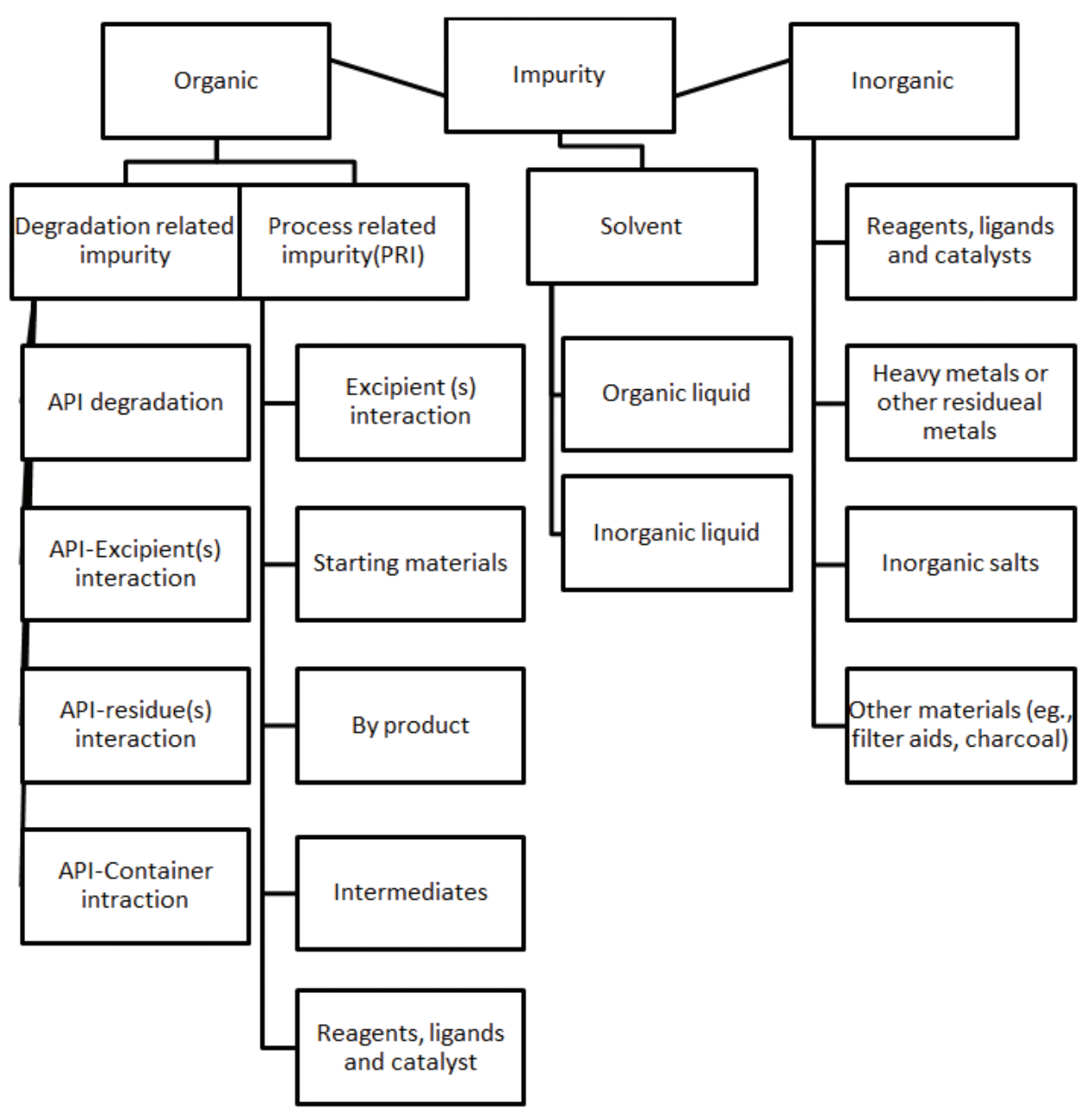

Fig. 1: Classification of impurities

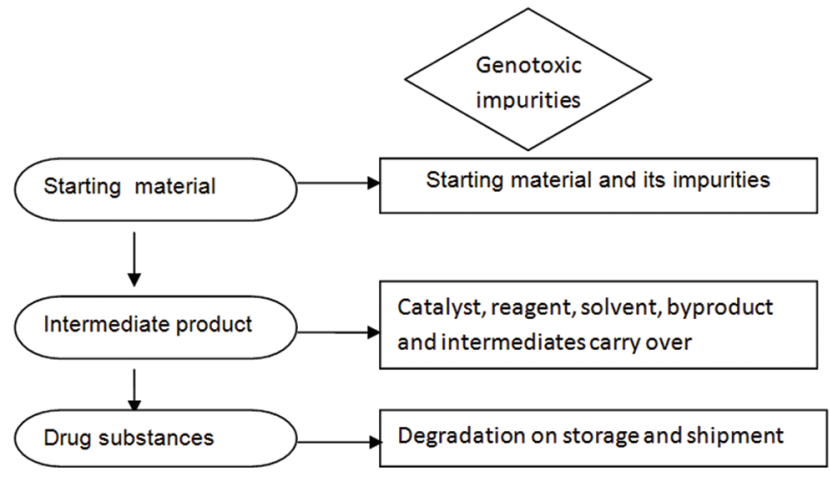

Fig. 2: Sources of genotoxic impurities

data clarify the mechanism of GTIs. ICH Q3C (R4) specified these in class 2 solvents. The absence of any experimental data for evidence of GTIs mechanism but can be controlled "as low as reasonably practicable" accordance with ALARP principle. Limits of therapeutic toxic concentration (TTC) value of $1.5 \mathrm{~g} /$ day intake of GTI were considered under the acceptable limits [11].

\section{PhRMA approach}

It provides structural classification which consists of alerting functional groups. The presence of such structural moieties was known to be involved in mutation of DNA (Fig. 4).

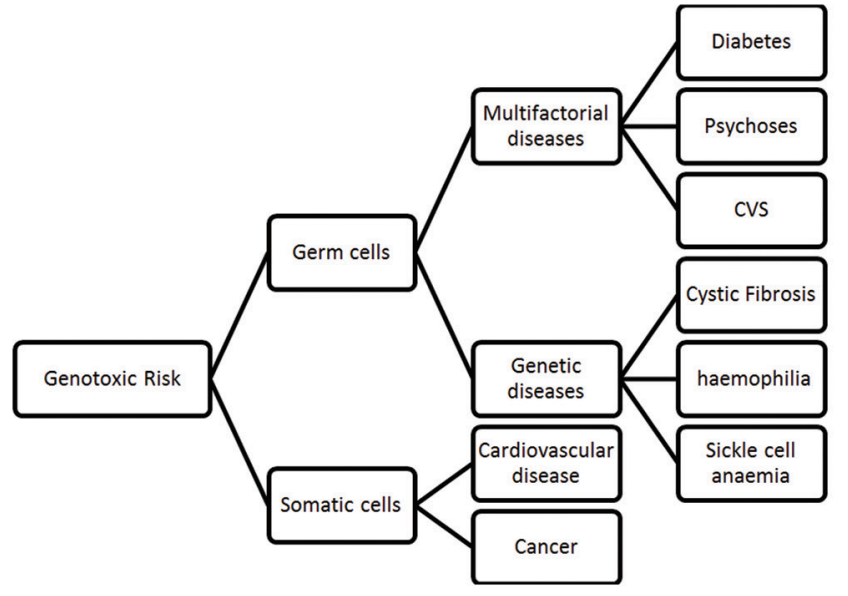

Fig. 3: Genetic risk flow chart

- Group 1: Aromatic groups, for example, $\mathrm{N}$ hydroxyaryls, $\mathrm{N}$-acylated amino-aryls, aza-aryl $\mathrm{N}$-oxides, amino-aryls and alkylated aminoaryls, purines or pyrimidines, intercalators, PNAs, or PNAHs

- Group 2: Alkyl and aryl groups, for example, aldehydes, N-methylols, $\mathrm{N}$-nitrosamines, nitro compounds, carbamates (urethanes), epoxides, aziridines, propiolactones, propiosulfones, $\mathrm{N}$ or $\mathrm{S}$ mustards (betahaloethyl), hydrazines, and azo compounds 
<smiles>ON(O)c1ccccc1</smiles>

$\mathrm{N}$-hydroxyaryls<smiles>CC(=O)C(C)c1ccccc1</smiles>

$\mathrm{N}$-acelated aminoaryls
Group 1: Aromatic groups<smiles>[O-][n+]1ccccc1</smiles>

Aza- aryl-N- oxides<smiles>CN(C)c1ccccc1</smiles>

Amino aryl and alkylated amino aryls

Group 2: Alkyl and aryl groups<smiles>[Y]C=O</smiles><smiles>CC(C)CO</smiles><smiles>[Y]N([Y])N=O</smiles><smiles>[3H]OC(N)=O</smiles><smiles>[Y]N[S+](=O)[O-]</smiles>

Aldehydes

$\mathrm{N}$-methylols

N-nitrosoamine

Carbamates

Nitro compounds

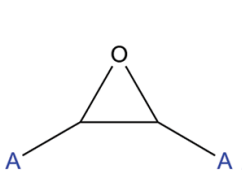<smiles>CC1NC1C</smiles><smiles>O=C1CCO1</smiles>

Halogen<smiles>O=[N+]([O-])CCO</smiles>

Epoxide

Aziridines

Propiolactomes

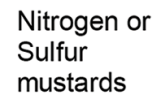<smiles>[R]N([Y])N([Y])[3H]</smiles>

\section{Hydrazines} and azo compounds

Group 3: Heteroatomic groups<smiles>C=CC(C)(C)C</smiles><smiles>CS(=O)O</smiles><smiles></smiles><smiles>CC[18OH]</smiles>

Michel reactive

Alkyl esters of phosphonates

Haloalkenes

Haloalkanes or sulfonates

Legends $\mathrm{A}=\mathrm{Alkyl}$, Aryl or $\mathrm{H}$

Halogens $=F, C L, B r$ and $I$

EWG = Electron withdrowing group

Fig. 4: Structure alerting functional groups<smiles>NNc1cccc([N+](=O)[O-])c1</smiles>

\section{3-NPH}

Fig. 5: Reaction of normal pressure hydrocephalus ( 3-NPH as an example) with aromatic aldehydes

- Group 3: Hetero aromatic groups, for example, Michael Reactive acceptors, alkyl esters of phosphonates or sulfonates, haloalkenes, and primary halides (alkyl and aryl- $\mathrm{CH}_{2}$ ).

PhRMA categorized impurities into five classes (Table 2) [12] USFDA

USFDA released draft guidance to address GTI issues which characterize and reduce the potential lifetime cancer risk associated with patient exposure to genotoxic and carcinogenic impurities. The recommended approaches include:

- Prevention of genotoxic and carcinogenic impurity formation

- Reduction of genotoxic and carcinogenic impurity levels (allowing a maximum daily exposure target of $1.5 \mathrm{~g}$ /day)

- Characterization of genotoxic and carcinogenic risk and<smiles>Nc1ccncc1</smiles>

Dalfampridine<smiles>c1cc(NNc2ccncc2)ccn1</smiles>

Impurity -III<smiles>NC(=O)c1ccncc1</smiles>

Impurity-I<smiles>Nc1cccnc1</smiles>

Impurity -II
Fig. 6: Five potential genotoxic impurities in dalfampridine

- Considerations for flexibility in approach to better support appropriate impurity specifications [13].

European Pharmacopoeial guidance

During revising or elaborating the monograph on GTI's, European Pharmacopoeia requires a pragmatic approach on GTIs. It says that the products that receive a marketing authorization after the issuance of 


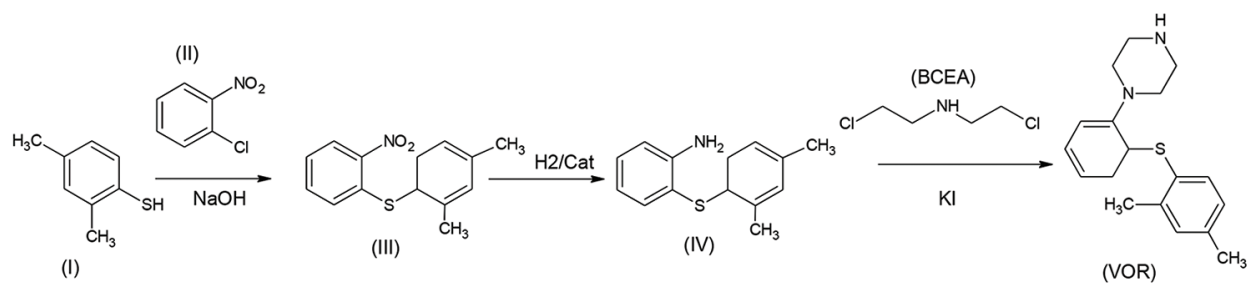

Fig. 7: Reaction scheme of voriconazole synthesis

Table 1: Genotoxic compounds in drug substances

\begin{tabular}{ll}
\hline Category/stage & Compounds \\
\hline Starting material & Hydrazine, nitroso, acrylonitrile compounds \\
Intermediate & Benzaldehyde, nitro compounds \\
By-product & Sulphonate esters, phosgene \\
Reagent & Formaldehyde, epoxides, esters of phosphate \\
& \&sulphonates \\
Solvent & Benzene, 1,2-dichloroethane \\
Catalyst & Toxic heavy metals, metal phosphates \\
Degradation product & N-oxides, aldehydes \\
\hline
\end{tabular}

Table 2: PhRMA classification of impurities

\begin{tabular}{|c|c|c|}
\hline Class & Definition & Proposed action for control \\
\hline C Class 1 & $\begin{array}{l}\text { Kkkknown carcinogens } \\
\text { with more risk of } \\
\text { genotoxicity }\end{array}$ & $\begin{array}{l}\text { C control at or below } \\
\text { compound specific } \\
\text { acceptable limits (TTC) }\end{array}$ \\
\hline C Class 2 & $\begin{array}{l}\text { Kno known mutagens } \\
\text { with unknown } \\
\text { carcinogenic potential }\end{array}$ & $\begin{array}{l}\text { Con control at or below } \\
\text { specific acceptable limits } \\
\text { (appropriate TTC) }\end{array}$ \\
\hline C Class 3 & $\begin{array}{l}\text { Drug structural alerts, not } \\
\text { related to drug structure } \\
\text { No genotoxic, mutagenic } \\
\text { data }\end{array}$ & $\begin{array}{l}\text { Control at or below } \\
\text { acceptable limits (TTC) or } \\
\text { conduct QSAR studies } \\
\text { Non-mutagenic=Class } 5 \\
\text { Mutagenic=Class } 2\end{array}$ \\
\hline C Class 4 & $\begin{array}{l}\text { Alerting structures are } \\
\text { same as that of functional } \\
\text { groups related to drugs } \\
\text { which are tested and } \\
\text { found to be nonmutagenic }\end{array}$ & Non-genotoxic impurity \\
\hline C Class 5 & $\begin{array}{l}\text { No structural alerts } \\
\text { with sufficient data, } \\
\text { evidence indicates } \\
\text { lack of genotoxicity or } \\
\text { carcinogenicity }\end{array}$ & Non-genotoxic impurity \\
\hline
\end{tabular}

TTC: Therapeutic toxic concentration, QSAR: Quantitative structure-activity relationship

the EMEA guideline have to be evaluated for the presence of GTIs and this should be the basis for a new monograph [14,15].

\section{Guidance for oncology products}

The USFDA draft guidance states, "a TTC value higher than $1.5 \mathrm{~g} /$ day may be acceptable in certain situations such as human exposure will be short term, treatment which is used for life-threatening conditions having life expectancy is $<5$ years, conditions where impurities were known substance as well as human exposure will be much greater from other sources." The ICH S9 guideline on nonclinical evaluation for anticancer pharmaceuticals also states, for genotoxic impurities, several approaches have been used to set limits based on increase in lifetime risk of cancer but it is not appropriate for pharmaceuticals intended to treat patients with advanced cancer and if it is used justifications should be considered to set higher limits for that particular pharmaceutical' $[16,17]$.

Risk assessment for genotoxic and carcinogenic substances European Commission Health and Consumer Protection Directorate.
General risk assessment methodologies and approaches for genotoxic and carcinogenic substances (2009).

- ICH Q3A () )-Impurities in new drug substances

- ICH Q3B () )-Impurities in new drug products

- ICH Q3C-Guidance for Residual solvents [18].

The standard test battery for genotoxicity recommends the following for genotoxicity evaluation (Table 3) [19]

Table 3: The genotoxicity evaluation or testing guidelines

TG 471 Bacterial reverse mutation test (ames test)

TG 472 Genetic toxicology: Escherichia coli, reverse assay

TG 473 In vitro mammalian chromosome aberration test

TG 474 Mammalian erythrocyte micronucleus test

TG 475 Mammalian bone marrow chromosome aberration test

TG 476 In vitro mammalian cell gene mutation test

TG 477 Genetic toxicology: Sex-linked recessive lethal test in drosophila melanogaster

TG 478 Genetic toxicology: Rodent dominant lethal test

TG 479 Genetic toxicology: In vitro sister chromatid exchange assay in mammalian cells

TG 480 Genetic toxicology: Saccharomyces cerevisiae, gene mutation assay

TG 481 Genetic toxicology: Saccharomyces cerevisiae, mitotic recombination assay

TG 482 Genetic toxicology: DNA damage and repair, unscheduled DNA synthesis in mammalian cells in vitro

TG 483 Mammalian spermatogonial chromosome aberration test

TG 484 Genetic toxicology: Mouse spot test

TG 485 Genetic toxicology: Mouse heritable translocation assay

TG 486 Unscheduled DNA synthesis (UDS) test with mouse liver cells in vitro

TG 487 In vitro mammalian cell micronucleus test

Tests to investigate the in vivo relevance of in vitro mutagens (positive bacterial mutagenicity (Table 4) [20]

Table 4: Tests to investigate the in vivo relevance of in vitro mutagens (positive bacterial mutagenicity)

\begin{tabular}{ll}
\hline In vivo test & $\begin{array}{l}\text { Factors to justify choice of test as fit-for- } \\
\text { purpose }\end{array}$ \\
\hline $\begin{array}{l}\text { Transgenic } \\
\text { mutation assays }\end{array}$ & $\begin{array}{l}\text { For any bacterial mutagenicity positive. Justify } \\
\text { selection of assay tissue/organ }\end{array}$ \\
$\begin{array}{l}\text { Pig-a assay } \\
\text { (blood) }\end{array}$ & $\begin{array}{l}\text { For directly acting mutagens (bacterial } \\
\text { mutagenicity positive without S9)* }\end{array}$ \\
$\begin{array}{l}\text { Micronucleus test } \\
\text { (blood or bone }\end{array}$ & $\begin{array}{l}\text { For directly acting mutagens (bacterial } \\
\text { mutagenicity positive without S9) and }\end{array}$ \\
marrow) & compounds known to be clastogenic* \\
unscheduled DNA & In particular for bacterial mutagenicity positive \\
synthesis (UDS) & to be generated in test species used to induce \\
test & bulky adducts \\
Comet assay & Justification needed (chemical class specific \\
& $\begin{array}{l}\text { mode of action to form alkaline labile sites or } \\
\text { single-strand breaks as preceding DNA damage }\end{array}$ \\
& that can potentially lead to mutations justify \\
Selection of assay tissue/organ
\end{tabular}

*These table enlisted the mutagenicity test which will helps to investigate the study of in-vitro mutation caused by in-vitro mutagens 


\section{TECHNIQUES TO DETECT GENOTOXIC IMPURITIES}

To analyze the impurities sensitive, selective, and robust analytical methods required to build rational and sufficient control strategies for GTIs. The selection of methodology for analyzing GTIs depends on target specifications, expected values for these impurities to comply with regulatory point of view. Therefore, a selected methodology should provide robust analytical data and the selected method can be used for routine testing burdens. Analytical techniques are selected based on genotoxic properties and the chemical properties of GTI's (given in Table 5) such as variety of structures, reactivities, and responsiveness to selected detection methods and potential matrix effects [21].

Quantitation of ppm level of GTIs presents in the pharmaceutical has many challenges to analytical chemist such as:

- Appropriate analytical technique selection for method development depending on properties of a GTI (volatility, thermal stability, presence of a chromophore, hydrophobicity, etc.)

- Feature of GTI such as reactive nature and stability of the GI must be reflecting during method development to provide evidence regarding requisite reproducibility and accuracy

- Selection of sensitive analytical method as well as clinical dose and duration of the study must be taken into the consideration during method development.

Analytical method to be developed, include parameters such as choice of the detection technique (ultraviolet [UV], light scattering,

Table 5: Genotoxic properties and the chemical properties GTI's

\begin{tabular}{|c|c|c|c|}
\hline $\begin{array}{l}\text { Genotoxicity } \\
\text { properties }\end{array}$ & Examples & $\begin{array}{l}\text { Chemical } \\
\text { properties }\end{array}$ & $\begin{array}{l}\text { Analytical } \\
\text { techniques }\end{array}$ \\
\hline \multirow[t]{2}{*}{ DNA reactive } & $\begin{array}{l}\text { Alkylating } \\
\text { electrophiles, } \\
\text { epoxides, azo } \\
\text { compounds }\end{array}$ & $\begin{array}{l}\text { Unstable, polar, } \\
\text { low molecular } \\
\text { weight }\end{array}$ & $\begin{array}{l}\text { Derivatization } \\
\text { followed byby } \\
\text { GC-MS or } \\
\text { LC-MS }\end{array}$ \\
\hline & $\begin{array}{l}\text { Aromatic } \\
\text { amines, } \\
\text { aromatic nitro } \\
\text { compounds }\end{array}$ & $\begin{array}{l}\text { Stable, moderate } \\
\text { polarity, variable } \\
\text { molecular weight }\end{array}$ & $\begin{array}{l}\text { Direct analysis } \\
\text { by GC-MS or } \\
\text { LC-MS }\end{array}$ \\
\hline $\begin{array}{l}\text { DNA } \\
\text { intercalation }\end{array}$ & $\begin{array}{l}\text { Polyaromatic } \\
\text { hydrocarbons, } \\
\text { polynuclear } \\
\text { aromatics, } \\
\text { cytostatic } \\
\text { molecules }\end{array}$ & $\begin{array}{l}\text { Stable, low to } \\
\text { moderate polarity, } \\
\text { moderate to high } \\
\text { molecular weight }\end{array}$ & $\begin{array}{l}\text { Direct analysis } \\
\text { by LC-MS }\end{array}$ \\
\hline
\end{tabular}

GC-MS: Gas chromatography-mass spectroscopy, LC-MS: Liquid

chromatography-mass spectrometry, GTI: Genotoxic impurity electrochemical detection, mass spectrometry, etc.). Sample matrix challenges also interfering matrix components which are eliminated by:

- Isolation of the analyte of interest by sample preparation

- chromatographic resolution, or

- Using a more selective detector.

A wide variety of analytical techniques can be used to analyze GTI. Due to their high structural diversity, complexity of the sample matrix, it is difficult to select a single ideal method. But ideally, no single approach is applicable to sort out all problems. As time passes out various conventional separations, hyphenated techniques, as well as software based in silico drug designs are widely used now.

Analytical laboratories in many pharmaceutical industry follows systematic strategies for GTI method development have 2 steps:

- Evaluation of the volatility of the analyte to select chromatographic techniques

- Selection of a detection techniques based on the properties of the analyte such as presence of a chromophore and presence of a halogen atom within the molecule.

\section{CONVENTIONAL SEPARATION TECHNIQUES}

\section{High-performance liquid chromatography (HPLC)}

Compounds which are nonvolatile and having aromatic or other structural features can be analyzed by HPLC with UV detection. The impurities and the API have structural similarity show excellent selectivity of the HPLC method and give accurate quantitation. Reversed-phase HPCL (RP-HPLC) also widely used now. For extremely polar analytes, hydrophilic interaction LC (HILIC) can be used to achieve sufficient retention. However, GTIs which enable to respond LC conditions or with a low response to UV detection, required chemical derivatization to increase the sensitivity of analysis by HPLC-UV method. Alternate to UV detection and to increase sensitivity-selectivity of low parts-per-million levels of GTIs, alternate detectors such as evaporative light scattering detectors or charged aerosol detectors may be used [22].

\section{Chloramphenicol}

2, 4-DNPH derivatization used to determine 4-nitrobenzaldehyde in injection formulations by HPLC-UV derivatization analysis method. For the extraction and concentrate, the derivatization products salt-assisted liquid-liquid microextraction technique was used, it also increased the sensitivity toward analysis. The complex nature of the concentrated derivatives, less volatility of the analyte hindered the analysis, therefore 4-NBA in drug was converted into 3-nitrophenylhydrazone (Fig. 5). 3-normal pressure hydrocephalus hydrochloride $(\mathrm{HCl})$ had good sensitivity was selected for derivatization and quantitation of GTIs [23].

Table 6: International guidelines outlining regulatory requirements for the control and test of IMPs/DPs in drug substances and products for human use

ICH (USA, EU, Japan) Q3A(R2): Impurities in new drug substances Q3B(R2): Impurities in new drug products

Q3C(R5): Impurities; guidelines for for residual solvents

Q3D: Impurities: Guideline for metal impurities (final concept paper)

EMA (Europe) M7: Assessment and control of DNA reactive (mutagenic) impurities in pharmaceuticals to limit potential carcinogenic risk (final concept paper) EMEA/CHMP/CVMP/QWP/450653/2006 assessment of quality of medicinal products containing existing/known active substances CPMP/QWP/1529/04: Control of impurities of pharmacopoeial substances CPMP/SWP/5199/02 and EMEA/CHMP/QWP/251344/2006: Guidelines on the limits of genotoxic impurities CPMP/SWP/QWP/4446/00 corr: Guidelines on Specification limits for residues of metal catalysts

$\begin{array}{ll} & \text { EMA/CHMP/CVMP/QWP/199250/2009: Guideline on setting specifications for related impurities in antibio } \\ \text { USFDA (USA) } & \text { NDAs: Impurities in drug substances genotoxic and carcinogenic impurities in drug substances and products: }\end{array}$ Recommended approach (draft) ANDAs: Impurities in drug products

TPD (Canada) Impurities in Existing Drug Substances and Products (draft)

TGA (Australia) Australian regulatory guidelines for prescription medicines: Appendix 18: Impurities in active pharmaceutical ingredients and finished products 
Table 7: Protocol variations for genotoxicity testing in vitro and in vivo according to various regulatory guidelines

\begin{tabular}{ll}
\hline $\begin{array}{l}\text { India (Ministry of } \\
\text { Health and Family }\end{array}$ & $\begin{array}{l}\text { United States (FDA's Centre } \\
\text { for Drug Evaluation and } \\
\text { Welfare) }\end{array}$ \\
$\begin{array}{l}\text { Research) } \\
\text { If the drug or its } \\
\text { metabolites is related to } \\
\text { a known carcinogen }\end{array}$ \\
$\begin{array}{l}\text { Two species should be } \\
\text { used for carcinogenicity } \\
\text { studies }\end{array}$ & $\begin{array}{l}\text { In vitro matagenicity test } \\
\text { mutalian cell }\end{array}$ \\
\end{tabular}
studies

At least 3-dose level should be used
Mammalian chromosome test in vitro

European community
(The Commission of
the European Union)
An in vitro test for gene
mutation in bacteria
An in vitro test for
gene mutation in
eukaryotic test system
(mammalian cells)

An in vitro test for chromosomal aberration.
Control group should always be included

\section{In vitro mammalian cell} transformation assay
An appropriate in vivo Additional test assay (usually test for chromosomal aberration).

Cytogenic tests in vivo (e.g.

Japan (Ministry of Health and Welfare)

Bacterial reversion test

In vitro chromosomal aberration test In vivo micronucleus test

(a) Continuous treatment for 24 and 48 hours (with and without S9 mix)

(b) Pulse treatment for 6 hours (with and without S9 mix followed by sampling at $24 \mathrm{~h}$

(c) Chromosome preparation for the presence of polyploidy cells (d) Use of single sex (male) in rodent micronucleus test

$\begin{array}{ll}\text { Canada (Health } & \text { ICH (Regulatory } \\ \text { Protection } & \text { authorities f EU, } \\ \text { Branch) } & \text { Japan and USA) } \\ \text { Salmonella/ } & \text { A test for gene } \\ \text { microsome } & \text { mutation in } \\ \text { assay } & \text { bacteria } \\ \text { Mammalian } & \text { In vitro } \\ \text { in vitro } & \text { chromosomal } \\ \text { chromosome } & \text { damage with } \\ \text { aberration } & \text { mammalian cells } \\ \text { assay } & \text { or an in vitro tk } \\ & \text { assay } \\ \text { Mammalian } & \text { In vitro test for } \\ \text { in vivo assay } & \text { chromosomal } \\ \text { (either meta } & \text { damage } \\ \text { phase or } & \text { using rodent } \\ \text { micronucleus } & \text { haemopoietic } \\ \text { test) } & \text { cells. } \\ \text { Positive in } & \text { Additional tests } \\ \text { vivo results } & \text { Measurement of } \\ \text { may need } & \text { DNA adducts } \\ \text { additional in } & \\ \text { vivo germ cell } & \\ \text { assay } & \\ & \\ & \\ & \\ & \\ & \\ & \\ & \end{array}$

DNA-strand breaks

DNA repair or recombination

test, liver unscheduled DNA

synthesis [UDS] test)

Further in vivo test

selection is left to applicant

ICH: International Council for Harmonization, FDA: Food and Drug Administration

\section{Dalfampridine}

HPLC utilizing a HILIC Technique was applied to determine five potential genotoxic impurities (PGI's) in dalfampridine. It has sensitivity to detect impurities at low level up to 7.5 ppm for Impurity-I, Impurity-II, Impurity-III, Impurity-IV, and Impurity-V (Fig. 6) [24].

\section{Voriconazole}

GTIs in the manufacturing process of voriconazole were detected, quantified and controlled by RP-HPLC method in combination with photo chemically induced fluorescence (PIF) detection for the analytical control of GTIs in the formulation. GTI properties were evaluated by PIF detector and utilized for its selective detection and sensitive quantification compared with the commonly used UV detection methods. The aminosulfide and nitrosulfide used as raw material known to be potential GTIs were predicted to be mutagenic by DEREK Nexus version 2.0 and further confirmed by an Ames bacterial mutagenicity test (Fig. 7). Therefore, aminosulfide and nitrosulfide impurities were confirmed as genotoxic, need to quantify by accurate, sensitive, and quantitative method such as RP-HPLC method in combination with PIF [25].

\section{Febuxostat}

Hydroxylamine and its salts act as reducing agents in myriad organic and inorganic reactions. Hydroxylamine $\mathrm{HCl}$ reagent is used in the synthesis of febuxostat for febuxostat ethyl ester intermediate preparation from formyl febuxostat ethyl ester. From which hydroxylamine $\mathrm{HCl}$ found to be mutagenicity in the mouse lymphoma $t k$ mutation assay. Therefore, hydroxylamine was determined and quantified by benzaldehyde derivatization procedure by HPLC. The derivatization mechanism is shown in Fig. 8 [26].

\section{Linagliptin: (UPLC)}

Linagliptin subjected to various conditions for degradation study, it was degraded at acidic condition and formed one unknown degradation product (impurity I) which was detected in HPLC. It was isolated, identified, and characterized by the spectral data (MS, MS/MS, 1D NMR, 2D NMR, and infrared spectrum) and finally impurity I was confirmed. The formed degradation product (impurity I) and another process-related impurity (impurity II) showed structural alerts of GTIs containing $N$-Acylated aminoaryl and alkyl halide, respectively, as a structural groups (Fig. 9). Hence, there is a need analyzed linagliptin by a rapid and sensitive method such as facile ultra-HPLC method was developed for simultaneous determination of these two PGI at trace level (ppm levels) in linagliptin [27].

\section{MLN9708}

MLN9708 is an investigational small-molecule proteasome inhibitor; undergo drug development studies done by Millennium: The Takeda Oncology Company in multiple clinical studies for the treatment of a broad range of human malignancies. MLN9708 drug initially evaluated for in silico studies for GTIs which includes starting materials, reagents, and intermediates used in the manufacturing process as well as for the process impurities and degradation products. Among them, 2,5-dichlorobenzoyl chloride (DCBC) which was a synthetic intermediate in the synthesis was reported to be mutagenic by DEREK Nexus version 2.0 and TOPKAT version 6.2 as an structural alert functional group such as acyl halide (Fig. 10). Due to multiple acid/base work-up steps in the 


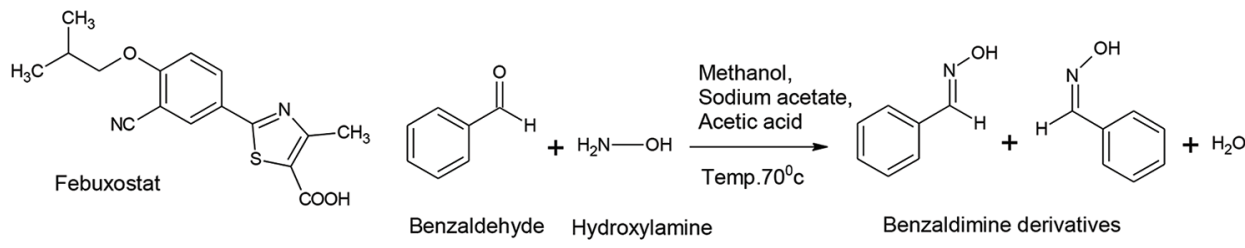

Fig. 8: Chemical structure of febuxostat and reaction mechanism of derivatization procedure<smiles>CC#CCN1C(=O)C2C(=O)N(C)C(N3CCC[C@@H](N)C3)=NC2N1Cc1nc(C)c2ccccc2n1</smiles>

Linagliptin<smiles>CC#CCN1C(N2CCC[C@@H](N)C2)=NC2C1C(=O)N(CC(=O)Nc1ccccc1C(C)=O)C(=O)N2C</smiles>

Impurity - I<smiles>Cc1nc(CCl)nc2ccccc12</smiles>

Impurity - II

Fig. 9: Structures of linagliptin and two potential genotoxic impurities<smiles>CC(C)C[C@H](NC(=O)CNC(=O)c1cc(Cl)ccc1Cl)B1OC(=O)CC(CC(=O)O)(C(=O)O)O1</smiles>

MLN9708 drug<smiles>O=C(Cl)c1cc(Cl)ccc1Cl</smiles>

2,5-dichlorobenzoyl chloride (DCBC)<smiles>O=C(O)c1cc(Cl)ccc1Cl</smiles>

2,5-dichlorobenzoic acid (DCBA)

Fig. 10: Structures of MLN9708 drug substance 2,5-dichlorobenzoyl chloride (DCBC) and 2,5-dichlorobenzoic acid<smiles>CCCCC(=O)N(Cc1ccc(-c2ccccc2-c2nn[nH]n2)cc1)[C@@H](C(=O)O)C(C)C</smiles><smiles>CN(C)N=O</smiles><smiles>CCN(CC)N=O</smiles>

$\mathrm{N}$-nitrosodimethylamine (NDMA) and $\mathrm{N}$-nitrosodiethylamine (NDEA).

Fig. 11: Structure of valsartan, $\mathrm{N}$-nitrosodimethylamine and $\mathrm{N}$-nitrosodiethylamine<smiles>Cc1ccccc1C(=O)Nc1ccc(C(=O)N2CCCC(O)c3cc(Cl)ccc32)c(C)c1</smiles><smiles>CCOC(=O)CCCBr</smiles>

Ethyl-4-bromobutyrate

Fig. 12: Chemical structure of tolvaptan and ethyl 4-bromobutyrate

manufacturing process, the risk of DCBC reported to be less but to assure that required to developed an accurate, sensitive, and quantifiable method. Therefore, it was an important to quantify the impurities in the view of regulatory point of view. Hence, the

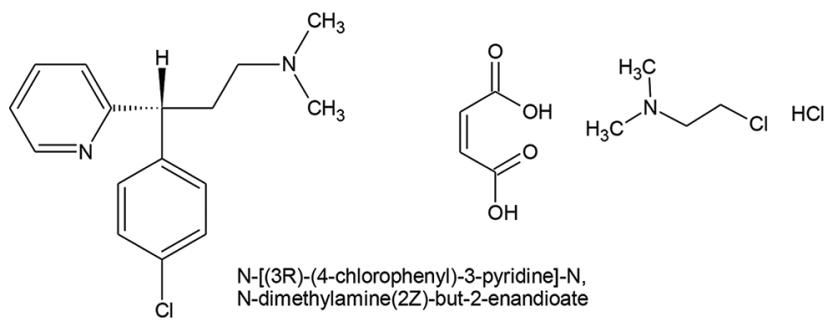

Fig. 13: Structures of chlorpheniramine maleate and dimethylaminoethyl chloride hydrochloride (its genotoxic impurity)

UHPLC/HRQMS method was developed, justified, and validated for the determination of DCBC in MLN9708 drug substance at low-level detection [28]. 

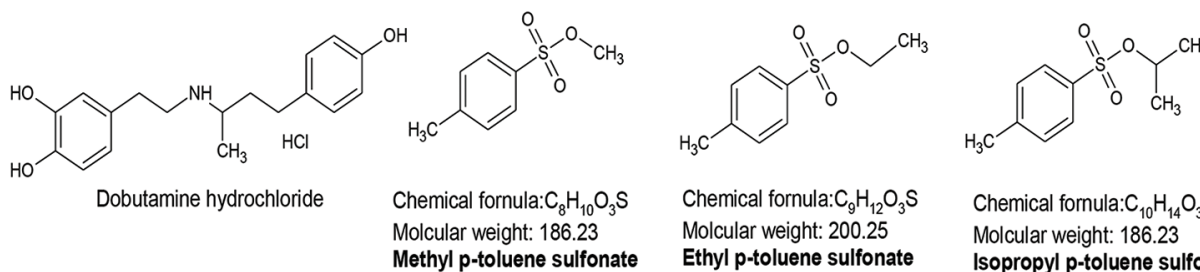

Chemical fornula: $\mathrm{C}_{10} \mathrm{H}_{14} \mathrm{O}_{3} \mathrm{~S}$

Molcular weight: 186.23

Isopropyl p-toluene sulfonate

Fig. 14: Chemical structure of dobutamine hydrochloride, methyl p-toluene sulfonate, ethyl p-toluene sulfonate, and Isopropyl p-toluene sulfonate

\section{B. HYPHONATAED TECHNIQUES}

Gas chromatography-mass spectroscopy (GCMS)

GC/MS-a combination of two GC and MS, used to analyze complex organic as well as biochemical mixtures. GC can be used to separate volatile and semi-volatile compounds with high resolution. MS provide structural data of compounds such that they can be exactly identified and quantified, but cannot separate out. Therefore, combination of gas chromatography and mass spectrometry is used widely and is highly compatible techniques [29].

\section{Valsartan}

Valsartan tablets contain, N-nitrosodimethylamine (NDMA) as an impurity. This impurity is classified as a human carcinogen, which was incorporated into the finished product as manufacturing process related impurity of the drug substance. GC/MS headspace method was implied to detect the presence of NDMA in Valsartan drug substance and drug products. Depending on limit of detection LOD and limit of quantitation LOQ (as 0.05 and 0.3 , respectively) the Valsartan tablets are recalled from the market (Fig. 11) [30,31].

\section{Divalproex sodium (DPS)}

Five genotoxic impurities, namely, methyl bromide (Me.-Br), ethyl bromide (Et.-Br), isopropyl bromide (Ipr-Br), n-propyl bromide (n-Pr.$\mathrm{Br}$ ), and n-butyl bromide (n-But.-Br) were evaluated and quantified in DPS drug substance using GC-EI-MS with SIM mode at a very low level [32].

\section{Tolvaptan}

Tolvaptan is synthesized using ethyl 4-bromobutyrate as a raw material in the intermediate manufacturing process of tolvaptan. It was reported as potential carcinogenic impurity as per its structure as primary alkyl halides. Hence, according to the ICH guidelines and regulatory point of view, there is a need to prove that the levels of ethyl 4-bromobutyrate were present below $1.5 \mu \mathrm{g} /$ day based on the maximum daily dose (MDD) of the drug. According to the TTC approach of the ICH guideline, the limit for ethyl 4-bromobutyrate potentially genotoxic impurity is found to be $25 \mathrm{ppm}$ for genotoxic impurities and based on the MDD, i.e., $60 \mathrm{mg} /$ day of tolvaptan (Fig. 12) [33].

\section{Chlorpheniramine/chlorpheniramine maleate}

2-dimethylaminoethyl chloride $\mathrm{HCl}$ (DMC $\mathrm{HCl}$ ) shows structural alert for genotoxic mutagenicity and carcinogenicity which was used as raw material in manufacturing of chlorpheniramine. Therefore, quantification of genotoxic impurity $\mathrm{DMC} \mathrm{HCl}$ is important at ppm level in chlorpheniramine/chlorphenamine maleate. For these, GC-MS method was used and detection limit and quantification limit found to be $0.94 \mathrm{ppm}$ and $3.75 \mathrm{ppm}$, respectively (Fig. 13) [34].

\section{Dobutamine $\mathrm{HCl}$}

A sensitive GC-MS method for analysis of residues of methyl-p-toluene sulfonate ethyl p-toluene sulfonate and isopropyl p-toluene sulfonate genotoxic impurities in dobutamine $\mathrm{HCl}$ drug substance (Fig. 14) [35].

\section{Fudosteine}

In the synthesis process of fudosteine, 3-chloro-1-propanol used as raw material, it consists of 1,3-dichloropropane, 3-chloropropylacetate, and chloropropyl hydroxypropyl ether as residual GTIs. According to regulatory point of view, these residual genotoxic impurities should be within the limits $<1.25 \mu \mathrm{g} / \mathrm{g}$ based on that a MDD of fudosteine is $1.2 \mathrm{~g}$. Therefore, the dichloromethane and $5 \mathrm{~N}$ sodium hydroxide solutions were used to extract the impurities and levels of these impurities monitored and controlled by GC-MS with SIM mode, as well as helium as the carrier gas for greater resolved chromatographic method [36].

\section{Nebivolol HCl}

Based on the structure of nebivolol, three genotoxic impurities present in the nebivolol $\mathrm{HCl}$, which was selectively determined and quantified using GC-MS method. The reported genotoxic impurities were found to be 2-chloro-1-(6-fluorochroman 2-yl)ethanone (1), 2-chloro-1-(6fluorochroman 2-yl)ethanol (2) and 6-fluoro2-(oxiran2-yl)chroman (3) in nebivolol $\mathrm{HCl}$ drug substance. These are shown in Fig. 15 [37].

\section{Zidovudine}

Methyl methanesulfonate (MMS) is known to be carcinogenic and genotoxin and was a potential process impurity of zidovudine (Fig. 16). MMS is incorporated by international agency for research on cancer in Group 2A. MMS is possible formed because of reaction between methane sulfonyl chloride and methanol to form corresponding mesylate during the manufacturing process which was incorporated in the final product. Therefore, MMS in zidovudine drug substance as GTI was detected using a gas chromatography technique with mass spectrometer as a detector [38].

\section{Folpet}

Folpet is a widely used protective fungicide in Switzerland, which contains two impurities such as carbon tetrachloride ( $\mathrm{CCl} 4)$ and perchloro-methylmercaptan which was determined by headspace GCMS (Fig. 17). CCl4 induces hepatic cell proliferation and DNA synthesis, also reported as mutagenic, induces aneuploidy and carcinogenic to humans (Group 2B) [39].

\section{Candesartan cilexetil}

Candesartan Cilexetil is an Angiotension II receptor antagonist synthesized with the use of 1 chloroethyl cyclohexyl carbonate, which is reported to be potential genotoxic impurity as per the EMEA guideline therefore certain limits was permitted based on daily dose basis and evaluation limit required was $0.49 \mu \mathrm{g} / \mathrm{mL}$ (i.e., $49 \mu \mathrm{g} / \mathrm{g}$ ) (Fig. 18). Therefore, most precise, accurate, and quantitative method such as GC technique with mass spectrometer as detector was selected [40].

\section{LC MS}

LC-MS is a versatile tool for the structural elucidation of impurities. It provides rapid, effective separation, and mass separations from the drug in the form of fragmented ions helps in characterization and structure elucidation of unknown impurities. The mass/charge ratio gives idea about molecular formulae. As LC-MS has high sensitivity and can detect impurities in femtogram level $\left(1 \mathrm{fg}=10^{-\mathrm{gi}} \mathrm{g}\right)$ in bulk samples. The structural elucidation data of LC-MS provides evidence of route cause for a rise of impurities which will further helps in controlling the impurity levels in the drug product. LC-MS/MS in the study helped in identifying genotoxic impurities in trace levels, reducing the cost per analysis, ultra-low limit of quantitation and obtaining high throughput results [41]. 
<smiles>O=C(CCl)C1CCc2cc(F)ccc2O1</smiles>

2-chloro-1-(6-fluorochroman2-yl)ethanone<smiles>OC(CCl)C1CCc2cc(F)ccc2O1</smiles>

2-chloro-1-(6-fluorochroman2 -yl)ethanol<smiles>Fc1ccc2c(c1)CCC(C1CO1)O2</smiles>

6-fluoro-2-(oxiran-2-yl) chroman

Fig. 15: Chemical structure of 2-chloro-1-(6-fluorochroman-2-yl)ethanone, 2-chloro-1-(6-f luorochroman-2-yl)ethanol and 6-fluoro-2(oxiran-2-yl)chroman<smiles>CCC1OC(n2ccc(=O)[nH]c2=O)CC1N=[N+]=[N-]</smiles><smiles>CS(C)(=O)=O</smiles><smiles>[R]OS(C)(=O)=O</smiles>

Alkyl methanesulfonate formation

Fig. 16: Structure of zidovudine and general reaction of formation of alkyl methanesulfonate<smiles>NC(=O)OC(=O)c1ccccc1</smiles>

Pthalic anhydride<smiles>[CH2+][NH+]1C(=O)c2ccccc2C1=O</smiles>

Pthalimide

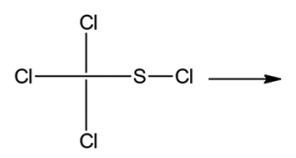

Perchloro methyl mercaptan<smiles>O=C1c2ccccc2C(=O)N1SC([18F])(Cl)Cl</smiles>

Folpet<smiles>C#CC#CCl</smiles>

Perchloro methyl mercaptan<smiles>[O+]C(Cl)(Cl)Cl</smiles>

carbon tetrachloride

Fig. 17: Reaction showing carbon tetrachloride as side product in the synthesis of folpet<smiles>CCOc1nc2cccc(C(=O)OC(C)OC(=O)OC3CCCCC3)c2n1Cc1ccc(-c2ccccc2-c2nnn[nH]2)cc1</smiles>

Fig. 18: Structure of candesartan cilexetil and 1-chloroethyl cyclohexyl carbonate

\section{Rabeprazole}

Rabeprazole contains 2 PRI originating from the route of synthesis of rabeprazole. The reported impurities were labeled as chloropropoxy analogue of rabeprazole and free base of chloro intermediate, as shown in Fig. 19. ICH-TTC provides certain limits based on the MDD of rabeprazole $(120 \mathrm{mg})$, the permitted level of these impurities in rabeprazole API is $12.5 \mathrm{ppm}$ /day and to quantify its trace level, LC-MS/ MS as a robust, precise, and accurate quantified method was selected with $\mathrm{QbD}$ principles. For the simultaneous examination numerical and categorical factors with UV detector, D-optimal experimental design was used [42].

\section{Pantoprazole sodium}

Rapid gradient LC-MS/MS method was used to simultaneous determination of three PGI in pantoprazole such as $\mathrm{N}$-(4-hydroxyphenyl) acetamide (GTI-A), N-(4- (difluoromethoxy) phenyl) acetamide (GTI-B) and 4-(difluoromethoxy)-2-nitroaniline (GTI-C) at a trace level (Fig. 20). The MRM mode in LC-MS/MS utilized for quantification of GTIs which provide better sensitivity and selectivity of analysis [43].

\section{Meropenem}

Meropenem was evaluated for its PRIs and was reported three impurities were formed (318-BP, M9, S5) during synthesis of meropenem which was identified as PGIs (Fig. 21). Based on the meropenem MDD (6g), 250 $\mathrm{ppb} /$ day level of these impurities in meropenem API is permitted [44] .

\section{Atazanavir sulfate}

Atazanavir sulfate synthesized using Tert-butyl 2-[4- (pyridine-2-yl) benzyl] hydrazine carboxylate (GTI-A) at early stage of drug synthesis (Fig. 22). However, it was reported as structural alert GTI; therefore, it is essential to control and prove that this material is not incorporated in final stage drug synthesis. For this, a sensitive LC-MS method selected for the determination of GTI-A, genotoxic impurity in atazanavir sulfate drug [45]

\section{Fluconazole}

1-[2-(2, 4-difluor-ophenyl)-2, 3-epoxypropyl]-1H-1, 2, 4-triazole was known to be genotoxic impurity used as intermediate of fluconazole API (Fig. 23). Fluconazole was synthesized by reacting its intermediate with triazole in the presence of a base result in formation of 2 GTI during process such as impurity-A, as 1-[2-(2,4-difluorophenyl)-2,3epoxypropyl]-1H-1,2,4-triazole (genotoxic impurity, as product-4) 


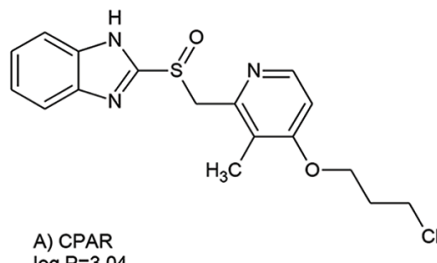

A) CPAR
$\log P=3.04$

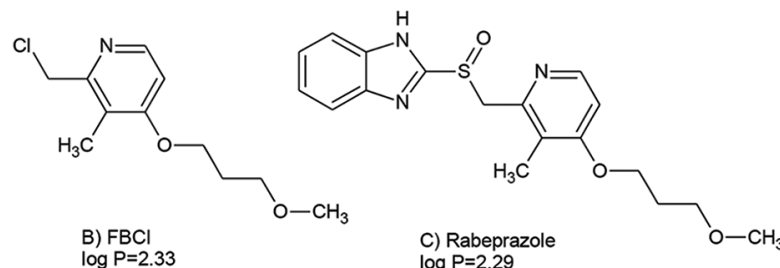

$\log P=2.29$

Fig. 19: Structures of (a) chloropropoxy analogue of rabeprazole, (b) free base of chloro intermediate, and (c) rabeprazole along with their $\log \mathrm{P}$ value

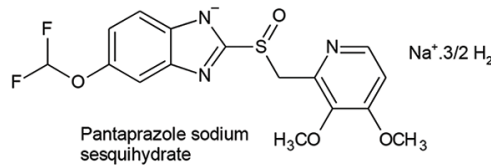

Fig. 20: Structure of pantoprazole sodium sesquihydrate and genotoxic impurities
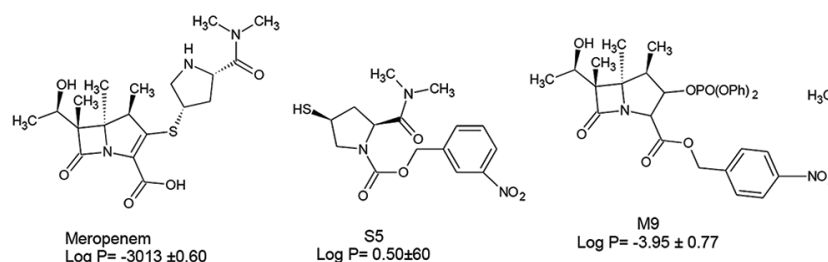

$M 9$
$\log P=-3.95 \pm 0.77$

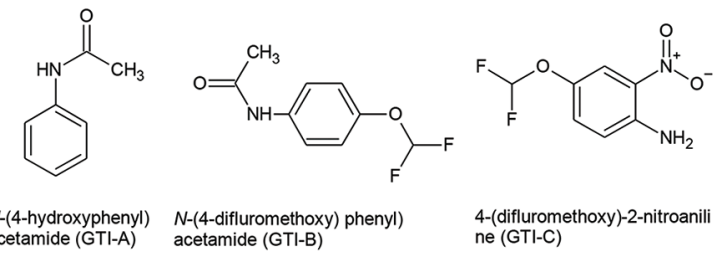

Fig. 21: Structures of meropenem and its potential genotoxic impurities along with their logP value<smiles>COC(=O)NC(C(=O)N[C@@H](Cc1ccccc1)[C@H](O)CN(Cc1ccc(-c2ccccn2)cc1)OC(=O)C(NC(=O)OC)C(C)(C)C)C(C)(C)C</smiles><smiles>CC(C)(C)OC(=O)NNCc1ccc(-c2ccccc2N)cc1</smiles>

Fig. 22: Structures of atazanavir sulfate and genotoxic impurity-A

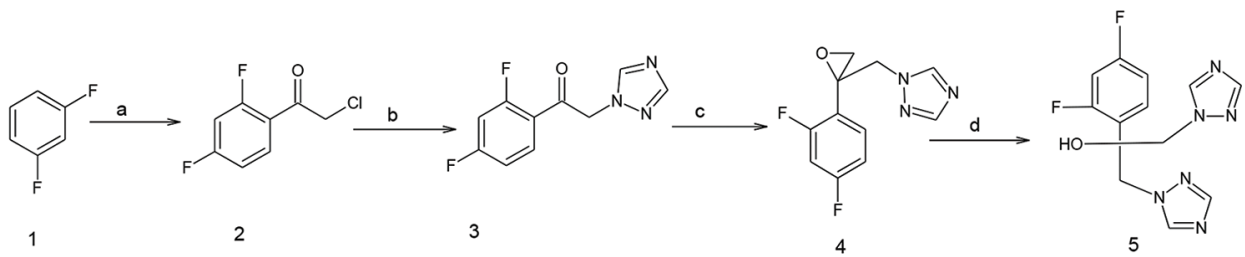

Fig. 23: Scheme of the synthesis of fluconazole (5), (a) $\mathrm{AlCl}_{3}$, Chloroacetyl chloride, (b) EtoAc, TEA, triazole, reflux, (c) toluene, NaOH, TMSOI, triazole, reflux, (d) DMF, triazole, anhy. $\mathrm{K}_{2} \mathrm{CO}_{3}, 90^{\circ} \mathrm{C}, 2.5 \mathrm{~h}$. genotoxic impurity (4) and precursor of genotoxic impurity (3)

and impurity-B, 1-(2,4-difluorophenyl)-2-[1,2,4]triazol-1-yl-ethanone (precursor of genotoxic impurity as product-5) are abbreviated as impurity A and impurity B. To determine such genotoxic impurity specific, selective, highly sensitive, and more accurate analytical method using LC-MS/MS coupled with positive electrospray ionization has been developed for the quantification of genotoxic impurity, 1-[2-(2,4-difluorophenyl)-2,3-epoxypropyl]-1H-1,2,4-triazole and its precursor, 1-(2,4-difluorophenyl)-2-[1,2,4]triazol-1-yl-ethanone at 0.3 $\mu \mathrm{g} / \mathrm{g}$ in fluconazole API. The method has been validated for specificity, linearity, accuracy, precision, robustness, and stability. This method is able to detect the impurities in the presence of other impurities and main drug [46].

\section{Efavirenz}

Aminoaryl derivative such a (2S)-(2-Amino-5-chlorophenyl)-4cyclopropyl-1, 1, 1-trifluoro-3-butyn-2-ol (AMCOL) was used as most important intermediate during the synthesis of efavirenz. However, a AMCOL reported as a structural alerting functional group containing 


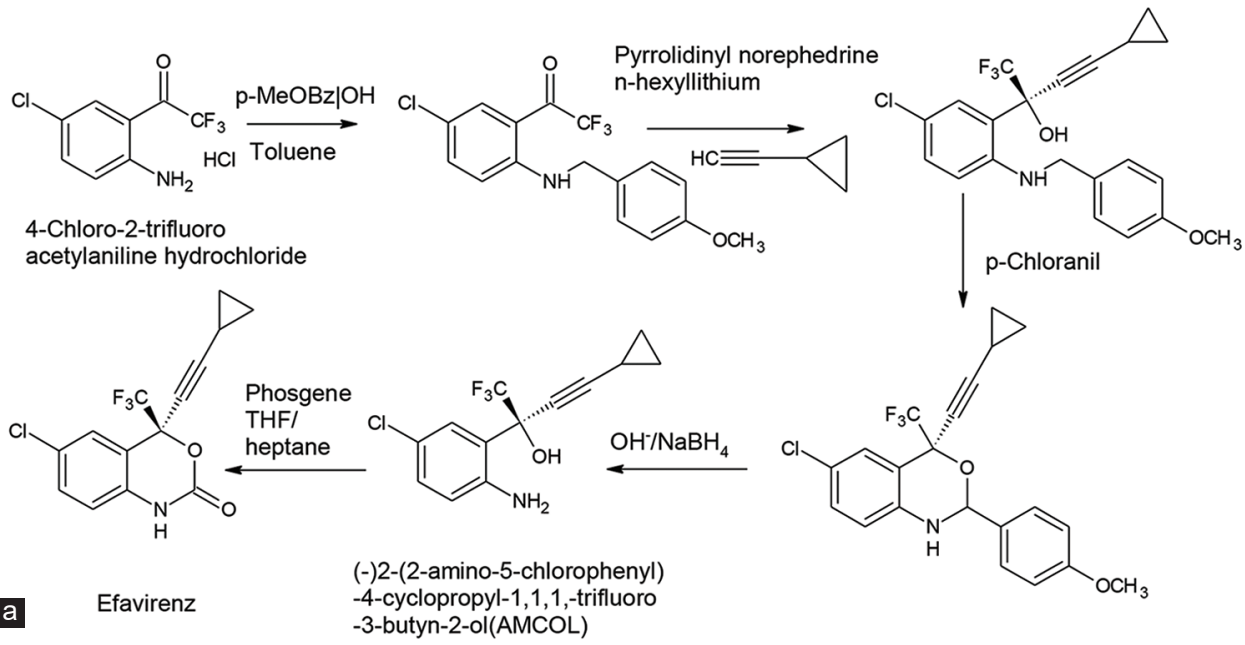<smiles>CC(F)(F)[C@@]1(C#CC2CC2)OC(=O)Nc2ccc(Cl)cc21</smiles>

b

Efavirenz<smiles>Nc1ccc(Cl)cc1[C@@](O)(C#CC1CC1)C(F)(F)F</smiles>

AMCOL

Fig. 24: (a) Schematic reaction mechanism showing the formation of (2S)-(2-Amino-5-chlorophenyl)- 4-cyclopropyl-1, 1, 1-trifluoro-3butyn-2-ol (AMCOL) during the synthesis of efavirenz, (b) schematic reaction showing the degradation of efavirenz to AMCOL

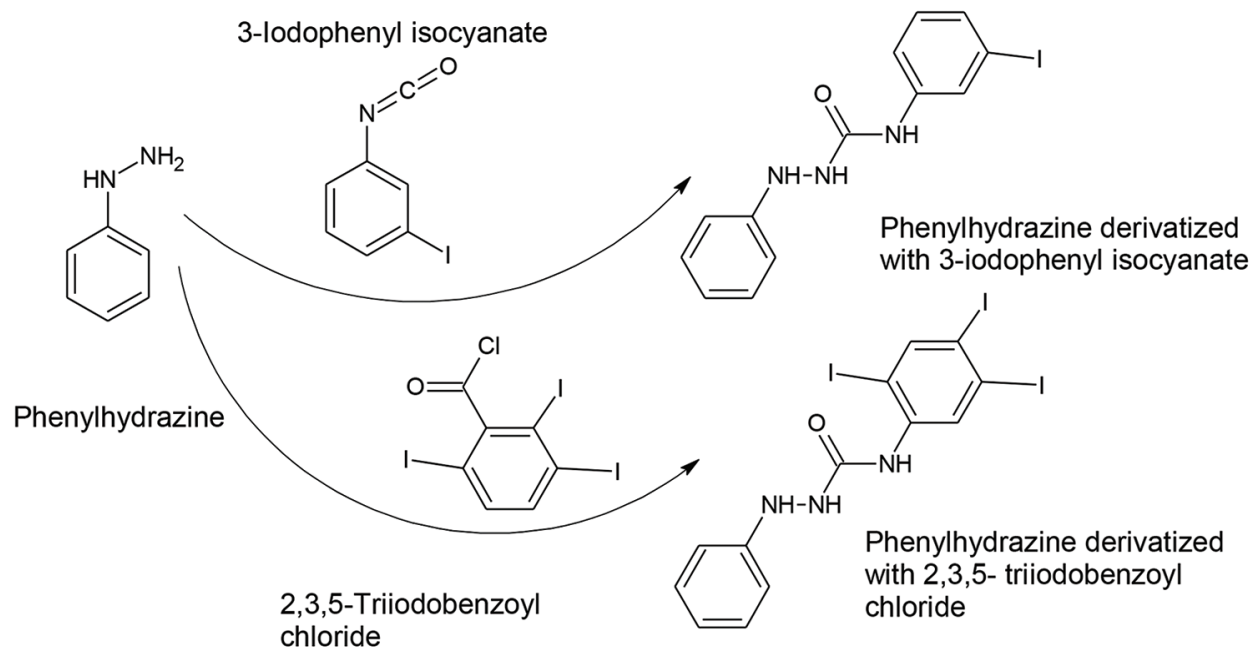

Fig. 25: Derivatization scheme for liquid chromatography -inductively coupled plasma -mass spectroscopy analysis

compound for genotoxic activity. Hence, it needs to identify as PGI present in a certain limit which was given by ICH and TTC for efavirenz API. To determined impurities, LC-MS/MS methods had been reported for trace level determination of AMCOL, which was a process-related impurity and degradation impurity of efavirenz also determined (Fig. 24) [47].

\section{Antipyrine}

Phenylhydrazine used as raw material in the synthesis of antipyrine, but it was reported as a genotoxic impurity. Residual phenylhydrazine in antipyrine was determined and analyzed using inductively coupled plasma-mass spectrometry combined with two-dimensional LC (LCICP-MS), was employed. LC-ICP-MS method with iodo derivatization 
using mono-iodo derivatization reagent (3-iodophenyl isocyanate or 3-iodobenzoyl chloride) (Fig. 25). Monoiodo derivatizing agents as well as tri-iodo derivatization reagent (2,3,5-triiodobenzoyl chloride) also utilized to increase the sensitivity of residual phenylhydrazine in APIs toward analysis. By comparing selectivity and sensitivity and detection limits obtained from two reagents was evaluated with regards of how much no. of iodine atoms was replaced by two different derivatizing agent and hence liquid chromatography -inductively coupled plasma mass spectrometry (LC-ICP-MS ) methods used with 3-iodophenyl isocyanate or 2,3,5-triiodobenzoyl chloride were applied as a derivatizing agent for the quantitation of residual phenyl hydrazine in antipyrine [48].

\section{Naproxen}

Naproxen is synthesized by using 2-Butyl p-toluenesulfonate, a most important intermediate, but it was reported as an impurity<smiles>COc1ccc2c(C)c(CC(=O)O)ccc2c1</smiles>

Naproxen:

(2-(6-methoxy-1-methyl-2-naphthyl) acetic acid

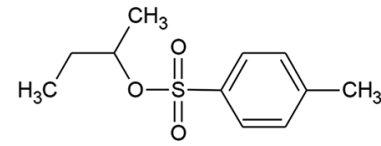

Genotoxic impurity (2-butyl p-toluenesulfnate)
Fig. 26: Chemical structures and chemical names of naproxen and its genotoxic impurity found to be genotoxic (Fig. 26). The impurity present in naproxen was found to be nucleophilic alkylating agent which was acting as anticancer to treat several cancers. It is toxic toward normal cells (cytotoxic) leading to damage bone marrow. However, naproxen is used as NSAID to treat pain or inflammation induced due to the various conditions. Therefore, it was needed to determine 2-butyl $p$-toluenesulfonate in drug which was tedious to analyze by HPLC, GC. Therefore, trace levels, such levels such as $1 \mathrm{ppm}$ of impurity in naproxen, were quantitatively determined using triple quad LCMS method [49].

\section{ADVANCED SOFTWARE BASED DRUG DESIGN}

\section{In silico methods}

A few decades ago, mutagenic activity of drugs, or chemicals predicted depending on their chemical structure and potential reactivity toward DNA. Two types of in silico system, i.e., substructures known to be responsible for interacting with DNA or the fragment-based quantitative structure activity relationship paradigm based on the experimental data sets (e.g., results obtained in the Ames test). In silico systems are accelerated drug discovery and provide occupational safety processes in industry and also can be used for in-house risk assessment of potential GTIs genotoxicity testing, but required some expert knowledgeable person for interpretation and validation of the in silico predictions.

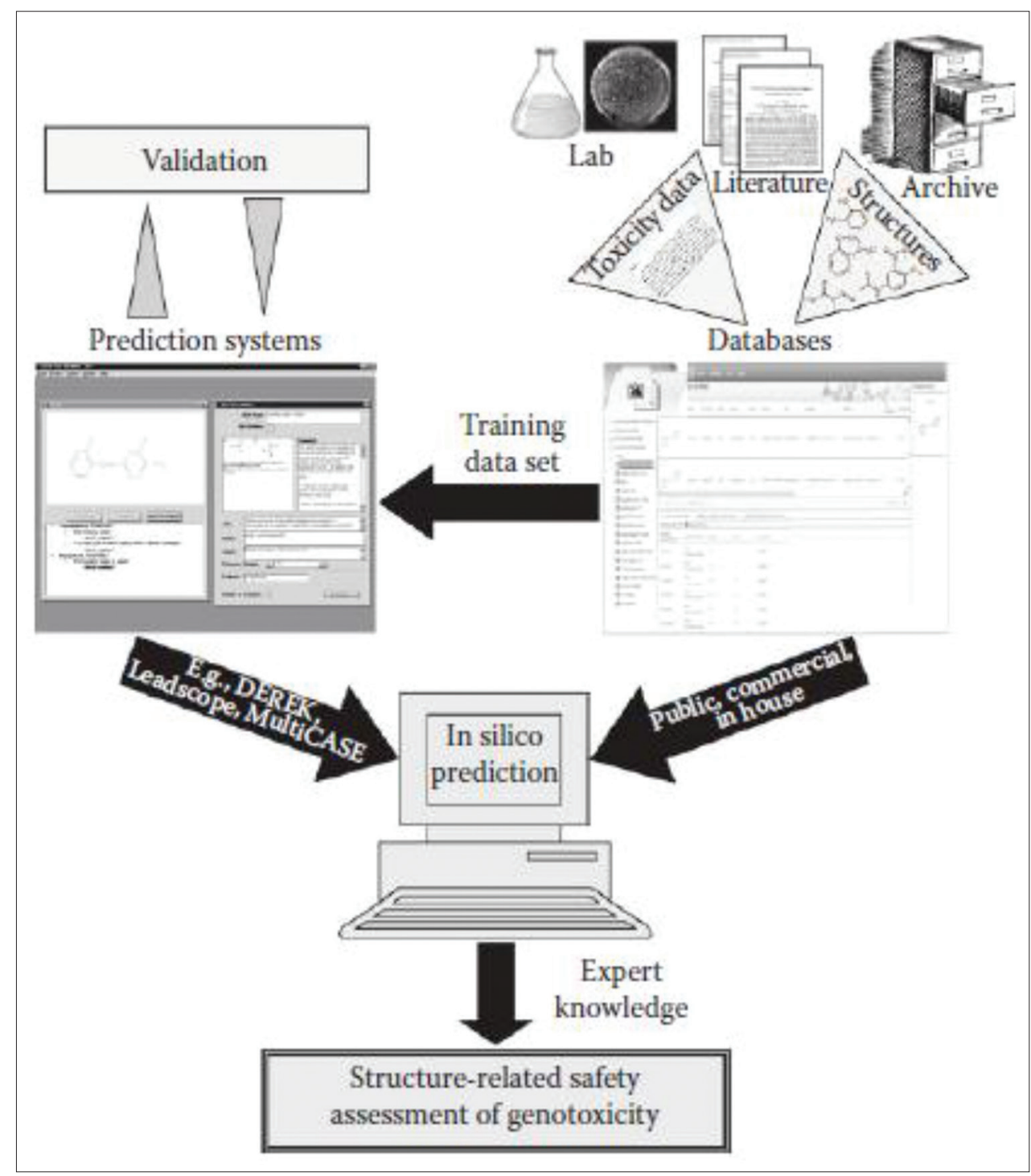

Fig. 27: Different tools used for the structure-related safety assessment of genotoxicity 
<smiles>C[C@@H]1COc2c(N3CCN(C)CC3)c(F)cc3c(=O)c(C(=O)O)cn1c23</smiles>

Levofloxacin<smiles>C[C@H]1COc2c(N3CCN(C)CC3)c(F)cc3c(=O)ccn1c23</smiles>

Descarboxyl levofloxacin

Fig. 28: Chemical structure of levofloxacin and descarboxy levofloxacin<smiles>CC(C)(O)c1ccccc1CCC(SCC1(CC(=O)O)CC1)c1cccc(/C=C/c2ccc3ccc(Cl)cc3n2)c1</smiles>

Montelukast<smiles>O=C(O)CC1(Cc2ccccc2)CCC(c2cccc(/C=C/c3ccc4ccc(Cl)cc4n3)c2)C(=O)C1</smiles>

Sulfoxide impurity

Fig. 29: Chemical structure of Montelukast and its Sulfoxide impurity

\section{Databases for in silico system}

It started with the collection of pre-existing data from toxicological journals, data safety sheets, and public databases that summarize genotoxicity results such as Ames test or mouse lymphoma assay because compounds are classified as GTIs based on their DNAreactive (mutagenic) activity. These databases can be searched by CAS number, compound name (should consider all synonyms), and chemical structure. Examples are databases provided by several regulatory authorities or organizations such as the International Uniform Chemical Information Database (IUCLID) (European Union), Informatics and Computational Safety Analysis Staff (FDA), Integrated Risk Information System (Environmental Protection Agency), National Toxicology Program (NTP), Toxicology Data Network (TOXNET), IPS INCHEM, and Japan Existing Chemical Data Base and Registry of Toxic Effects of Chemical Substances databases. Databases of carcinogenicity studies used in the in silico genotoxicity assessment of GTIs. However, before applying in silico methods, databases were first validated for robustness of a carcinogenicity assay such as number of animals sufficient, route of administration, and appropriate controls included, single compound or mixture tested, duration of study, and top dose sufficient. For instance, databases with carcinogenicity results include the Carcinogenic Potency Database, IUCLID, NTP, and TOXNET databases used for GTIs evaluation. Various regulatory bodies also provided various classifications and guidelines which are covered in guidelines section. VITIC, Leadscope, PharmaPendium, and SciFinder these are the commercially available databases which can be used for GTIs assessment (Fig. 27) [50].

\section{Levofloxacin}

Levofloxacin contained descarboxy levofloxacin is an impurity which had insufficient toxic information about descarboxy levofloxacin impurity. In silico and in vitro methods were applied to risk assessment of impurity. Derek-structure activity relationship software package was used for in silico study and the results reported that the levofloxacin contains quinoline as a structural alert impurity. It further evaluated by modified Ames test and by a chromosomal aberration test, using Chinese hamster lung cells. Both assays were conducted in the presence or absence of S-9 mix and their results were compared, on the basis of these assays, descarboxy levofloxacin could be controlled as a nongenotoxic impurity (Fig. 28) [51].

\section{Montelukast}

Montelukast evaluated for genotoxicological assessment considering regulatory approaches. RP-HPLC analysis was applied for the determination of impurities such as sulfoxide, cis-isomer, Michael adducts-I and II, methylketone and methylstyrene. However, sulfoxide impurity found to be present above the specified limits as well as the absence of toxicity data (Fig. 29). Therefore, computational program such as in silico mutagenicity prediction analysis done and further confirmed by miniaturizing bacterial gene mutation test, mitotic index determination and in vitro chromosomal aberration test $\mathrm{w} /$ wo metabolic activation system. Leadscope and ToxTree programs as well as Ames MPF Penta I assay predicted sulfoxide impurity as non-mutagenic. Sulfoxide impurity was reported as dose-dependent cytotoxic in human peripheral lymphocytes. After that, sulfoxide impurity should be considered as non-mutagenic and can be classified as ordinary impurity according to the guidelines [52].

\section{CONTROL STRATEGY FOR GTIS}

A control strategy is planned for current product and process understanding that gives assurance that the process performance and product quality free of GTIs (ICH Q10). A control strategy includes the following options:

- Controls on material attributes (including raw materials, starting materials, intermediates, reagents, solvents, and primary packaging materials)

- Facility and equipment operating conditions

- Controls implicit in the design of the manufacturing process

- In-process controls (including in-process tests and process parameters)

- Controls on drug substance and drug product (e.g., release testing) [53].

The FDA draft guidance was generally quite similar to EMEA guideline. Some notable exceptions are: 
- The FDA includes carcinogenic impurities (many carcinogens are non-genotoxic)

- The FDA includes additional safety margins for pediatric populations.

Control strategy 1 - avoidance

According to the EMEA decision tree in the 2006 guideline, during production avoidance of side reaction and formation of reactive molecules which may act as GTIs can be a control strategy.

Example: Various reaction involved acids with alcohols and can produce various alkylating agents such as alkyl halides, esters of aryl sulfonic acids (besilates and tosylates and esters of sulfuric acid), and esters of alkyl sulfonic acids (mesilates such as ethyl mesilate (EMS) and m EMS) all are reported to be potential GTIs. Such cases can be avoided by substituting such acids with alternative acids so that production of GTIs avoided.

\section{Control strategy 2 - adjust API process}

It is more troublesome/difficult to adjust optimal chemical process of API which leads to formation of GTIs. But by applying some strategies, we can control over GTIs.

\section{Examples are:}

- Placing GTIs early in the process so that the produced GTI will available longer duration for purging and will remain away from API forming step so that the GTI can be effectively controlled

- Placing solid isolations strategically in the process such as crystallization for the purification of intermediates and APIs, it will help in reduction or remove crucial GTIs.

\section{Control strategy 3 - demonstrate DTI threshold mechanism above} TTC level

High levels of EMS, a potential GTI, lead to a recall of Roche's Viracept (nelfinavir mesilate) in 2007. It was due to improper cleaning of vessels with ethanol for longer duration of time and further deposition of EMS. This cause was eventually traced to a GMP failure in the manufacture of the API. While Roche's investigation on in vivo rodent toxicology studies with EMS and threshold of $2 \mathrm{mg}$ EMS/ $\mathrm{kg}$ for DNA damage was determined. It was four orders of magnitude higher than the 1.5 mg/day TTC as per EMEA guideline. Based on this finding, the EMEA accepted a higher TTC for EMS. It has been speculated that this result may ultimately provide a new approach to guiding risk management for genotoxic impurities in pharmaceuticals. This may be particularly true for monofunctional alkylating agents that react with DNA as soft nucleophiles through an SN2 mechanism in a similar fashion as EMS [54].

\section{LIMITATIONS OF THE PRESENT REGULATORY SYSTEM TO TEST GENOTOXICITY}

Nowadays, it is necessary to provide information regarding mutagenicity and carcinogenicity of a NCE. Different regulatory authorities have differences in protocol design and practices for NCE and hindered the drug discovery process as well as delay the marketing of the potential candidates (Tables 6 and 7).

As per regulatory point of view, the preclinical safety study has to be performed in each country as per that country's regulatory guidelines. These are time consuming, contain intensive processes and need a large number of animals for experimentation. Most of the country's guidelines are inadequate to draw a final accurate conclusion for the genotoxic potential of a NCE. Different pharmaceuticals, different design, protocols, and critical experimental evaluation as well as different guidelines by a various regulatory agencies will results in delayed in regulatory approval of new chemical entities (NCI). Lack of specific test system and test protocols as well as guidelines are devoid of recommendations for compounds, which are genotoxic, but seem to act by non-DNA targets. There are no specific recommendations on the threshold of different genotoxic and tumorigenic compounds and their organ specific effects when they are intended to use therapeutically.
The guidelines recommended by various regulatory authorities have four-test battery.

- A gene mutation in bacteria

- A test for gene mutation in eukaryotic cells in vitro

- In vivo test for genetic damage

- A test for chromosome aberrations in mammalian cells in vitro.

When the results of all the tests in the four-test battery are uniformly negative, then the compound under study complies testing, but testing but if test results are not uniform then further experiments are suggested in the four-test battery $[55,56]$.

\section{CONCLUSION}

In this article, we have presented a detailed regulatory guidance on GTIs and different analytical approaches for quantification GTIs in drug formulation. The above discussion shows that the conventional way of quantitation and structure elucidation of GTIs by spectral analysis to the use of modern hyphenated techniques are widely adopted currently by the pharmaceuticals. In case of hyphenated systems such as LC, and GC with MS systems reported to be widely used in current scenario. Many studies have been reported studies on in silico methods, but they need to confirm by further analysis by the other in vitro or hyphenated techniques. This review concluded that the determination and quantitation of GTIs by the use of accurate, sensitive, and quantitative methods will give safety regulatory framework to the novel drugs, pharmaceuticals, and human beings. Furthermore, some control strategy summarized so that the GTIs can be controlled at initial stage of drug production.

\section{AUTHORS' CONTRIBUTIONS}

This work was compiled in collaboration among all authors. Author KRG wrote the final draft of the manuscript. Author ARP wrote the first draft of the paper. Author MJU managed the literature searches. All authors read and approved the final manuscript.

\section{CONFLICTS OF INTEREST}

The authors have declared that no competing interests exist.

\section{FUNDING SOURCE}

Nil/Self.

\section{REFERENCES}

1. Savale SK. Genotoxicity of drugs: Introduction, prediction and evaluation. Asian J Biomater Res 2018;4:1-29.

2. Liu KT, Chen CH. Determination of impurities in pharmaceuticals: Why and how? In: Quality Management and Quality Control: New Trends and Developments. London, United Kingdom: IntechOpen; 2019.

3. Gosar A, Sayyed H, Shaikh T. Genotoxic impurities and its risk assessment in drug compounds. Drug Design Intellect Properties Int J 2018;2:227-32.

4. EFSA Scientific Committee. Scientific opinion on genotoxicity testing strategies applicable to food and feed safety assessment. EFSA J 2011;9:2379.

5. Shah SU. Importance of genotoxicity and S2A guidelines for genotoxicity testing for pharmaceuticals. IOSR J Pharm Biol Sci 2012;1:43-54.

6. Guideline IH. Impurities in new drug substances Q3A (R2). In: Proceedings of the International Conference on Harmonization of Technical Requirements for Registration of Pharmaceuticals for Human Use. Geneva, Switzerland: 2006. Available from: https://www.database. ich.org/sites/default/files/Q3A_R2_Guideline.pdf. [Last accessed on 2019 Oct 31].

7. International Conference on Harmonisation Guideline on Impurities in New Drug Products, Q3B(R2); 2006. Available from: https://www.ema. europa.eu/en/documents/scientific-guideline/ich-q-3-b-r2-impuritiesnew-drug-products-step-5en.pdf. [Last accessed on 2019 Oct 31]

8. International Conference on Harmonisation Guideline for Residual Solvents, Q3C(R4); 2019. Available from: https://www.ema.europa. 
eu/en/documents/scientific-guideline/international-conferenceharmonisation-technical-requirements-registration-pharmaceuticalshuman-use_en-33.pdf. [Last accessed on 2019 Nov 01].

9. European Medicines Agency. Guideline on the Specification Limits for Residues of Metal Catalysts or Metal Reagents, Doc. Ref. EMEA/ CHMP/SWP/4446/2000. Netherlands: European Medicines Agency; 2013. Available from: https://www.ema.europa.eu/documents/ scientific-guideline/guideline-specification-limits-residues-metalcatalysts-metal-reagents en.pdf. [Last accessed on 2019 Oct 31].

10. European Medicines Agency. Guideline on the Limits of Genotoxic Impurities, CPMP/SWP/5199/02,EMEA/CHMP/QWP/251344/2006. European Medicines Agency; 2007. Available from: https://www.ema. europa.eu/documents/scientific-guideline/guideline-limits-genotoxicimpurities en.pdf. [Last accessed on 2019 Oct 31].

11. Kroes R, Renwick AG, Cheeseman M, Kleiner J, Mangelsdorf I, Piersma A, et al. Structure-based thresholds of toxicological concern (TTC): Guidance for application to substances present at low levels in the diet. Food Chem Toxicol 2004;42:65-83.

12. Muller L, Mauthe RJ, Riley CM, Andino MM, Antonis DD, Beels C, et al. A rationale for determining, testing and controlling specific impurities in pharmaceuticals that possess potential for genotoxicity, regul. Toxicol Pharmacol 2006;44:198-211.

13. Center for Drug Evaluation and Research, Food and Drug Administration. Guidance (Draft) for Industry Genotoxic and Carcinogenic Impurities in Drug Substances and Products: Recommended Approaches. United States: Center for Drug Evaluation and Research, Food and Drug Administration; 2008.

14. Connelly JC. ICH guideline residual solvents. Counc pharmeur 1997;1:S1-68.

15. Callis CM, Bercu JP, DeVries KM, Dow LK, Robbins DK, Varie DL. Risk assessment of genotoxic impurities in marketed compounds administered over a short-term duration: Applications to oncology products and implications for impurity control limits. Org Process Res Dev 2010;14:986-92.

16. Leighton JK, Olejniczak K, Onodera H. ICH S9: Nonclinical evaluation of anticancer pharmaceuticals: A perspective from regulators on the development of the guideline. In: Global Approach in Safety Testing. New York: Springer; 2013. p. 283-98

17. Venkatramani CJ, Sayah MA. Analytical strategies for genotoxic impurities in the pharmaceutical industry. Am Pharm Rev 2014;17:1-5.

18. Sultan S, Tengli A, Akhila G. Analytical assessment of genotoxic impurities in pharmaceuticals by gas chromatographic techniques. Res Rev 2019;1:22-32

19. Mohamed SA, Sabita U, Rajendra S, Raman D. Genotoxicity: Mechanisms, testing guidelines and methods. Glob J Pharm Pharm Sci 2017;1:1-6.

20. Guideline IH. Assessment and Control of DNA Reactive (Mutagenic) Impurities in Pharmaceuticals To Limit Potential Carcinogenic RISK M7. Geneva: International Conference on Harmonization of Technical Requirements for Registration of Pharmaceuticals for Human Use (ICH); 2018. Available from: https://www.fda.gov/regulatoryinformation/search-fda-guidance-documents/m7r1-assessment-andcontrol-dna-reactive-mutagenic-impurities-pharmaceuticals-limitpotential [Last accessed on 2019 Nov 02].

21. Pierson DA, Olsen BA, Robbins DK, DeVries KM, Varie DL. Approaches to assessment, testing decisions, and analytical determination of genotoxic impurities in drug substances. Org Process Res Dev 2009;13:285-91.

22. Helmy R, Strickfuss S, Al-Sayah M, Hamilton S, Bu X, Lee C, et al. Quantification of Genotoxic Impurities in Active Pharmaceutical Ingredients. United Kingdom; Taylor \& Francis Group; 2015. p. 293.

23. Luo L, Gu C, Li M, Zheng X, Zheng F. Determination of residual 4-nitrobenzaldehyde in chloramphenicol and its pharmaceutical formulation by HPLC with UV/Vis detection after derivatization with 3-nitrophenylhydrazine. J Pharm Biomed Anal 2018;156:307-12.

24. Jain M, Srivastava V, Kumar R, Dangi V, Hiriyanna SG, Kumar A, et al. Determination of five potential genotoxic impurities in dalfampridine using liquid chromatography. J Pharm Biomed Anal 2017;133:27-31.

25. Douša M, Doubský J, Srbek J. Utilization of photochemically induced fluorescence detection for HPLC determination of genotoxic impurities in the vortioxetine manufacturing process. J Chromatogr Sci 2016;54:1625-30.

26. Vundavilli A, Kumar J. Determination of hydroxylamine by HPLC, a mutagenic impurity in febuxostat drug substance. Int J Pharm Pharm Res 2018;12:318-30

27. Huang Y, Lu H, Zhang F, Min C. Identification, isolation, characterization, and UHPLC quantification of potential genotoxic impurities in linagliptin. J Sep Sci 2018;41:3985-94.

28. Fu M, Lu Q, Hewitt E, Wang J. Ultra high performance liquid chromatography coupled with high resolution quantitation mass spectrometry method development and validation for determining genotoxic 2, 5-dichlorobenzoyl chloride in MLN9708 drug substance. J Pharm Biomed Anal 2014;89:233-9.

29. Hussain SZ, Maqbool K. GC-MS: Principle, technique and its application in food science. Int J Curr Sci 2014;13:116-26.

30. Parr MK, Joseph JF. NDMA impurity in valsartan and other pharmaceutical products: Analytical methods for the determination of N-nitrosamines. J Pharm Biomed Anal 2018;164:536-49.

31. Division of Pharmaceutical Analysis, Center for Drug Evaluation and Research. GC/MS Headspace Method for Detection of NDMA in Valsartan Drug Substance and Drug Products. United States: Division of Pharmaceutical Analysis, Center for Drug Evaluation and Research; 2019.

32. Reddy SR, Reddy KH, Kumar MN, Reddy PM, Reddy JV, Sharma HK A validated GC-MS method for the determination of genotoxic impurities in divalproex sodium drug substance. J Chromatogr Sci 2018;57:101-7.

33. D'Souza AJ,Lokhande SR, Anvekar T. Development and validation of GCMS method for the detection and quantification of potential genotoxic impurity ethyl 4-bromobutyrate in tolvaptan tablets. Int J Res Appl Sci Eng Technol 2018;6:2460-5.

34. Zate PB, Kothari S, Lokhande MV. Confirmation and quantification of genotoxic impurity 2-dimethylaminoethyl chloride hydrochloride (DMC $\mathrm{HCl}$ ) by GCMS in chlorpheniramine/chlorphenamine maleate. J Appl Chem 2017;10:21-6.

35. Maddala VL, Ray PC, Rao KN. A sensitive and selective GC-MS method for analysis of genotoxic impurities in dobutamine hydrochloride. Orient J Chem 2016;32:1685-90.

36. Gooty AR, Katreddi HR, Hunnur RK, Sharma HK, Masani NK. Simultaneous determination of genotoxic impurities in fudosteine drugs by GC-MS. J Chromatogr Sci 2016;54:1277-81

37. Maddala VL, Ray PC, Venugopal K, Rao KM. A sensitive and selective GC-MS analysis of process related genotoxic impurities of nebivolol hydrochloride. Asian J Chem 2016;28:811-3

38. Kakasaheb NA, Ramakrishna K, Srinivasarao V. Genotoxic impurity method development and validation by GCMS for the analysis of methyl methane sulfonate (MMS) in zidovudine drug substance. ACAIJ 2015;15:184-9.

39. Patrian B, Poiger T, Müller MD. Carbon Tetrachloride in Folpet Formulations by Headspace GC-MS. Available from: http://www. agroscope.ch.

40. Kakasaheb NA, Ramakrishna K, Srinivasarao V. Method development and validation by GC-MS for quantification of 1-chloroethyl cyclohexyl carbonate as a genotoxic impurity in candesartan cilexetil drug substance. Int J Pharm Pharm Sci 2014;6:370-2.

41. Akshatha HS, Gurupadayya BM. Application of liquid chromatography coupled with mass spectrometry in the impurity profiling of drug substances and products. Asian J Pharm Clin Res 2018;11:30-7.

42. Iliou K, Malenović A, Loukas YL, Dotsikas Y. Analysis of potential genotoxic impurities in rabeprazole active pharmaceutical ingredient via liquid chromatography-tandem mass spectrometry, following quality-by-design principles for method development. J Pharm Biomed Anal 2018;149:410-8.

43. Subbaiah N, Reddy GR, Kanyawar N, Gangrade M. A selective and sensitive method development and validation by $\mathrm{Lc}-\mathrm{Ms} / \mathrm{Ms}$ approach for trace level quantification of three potential genotoxic impurities in pantoprazole sodium drug substance. Rasayan J Chem 2017;10:1080-87.

44. Grigori K, Loukas YL, Malenović A, Samara V, Kalaskani A, Dimovasili E, et al. Chemometrically assisted development and validation of LC-MS/MS method for the analysis of potential genotoxic impurities in meropenem active pharmaceutical ingredient. J Pharm Biomed Anal 2017;145:307-14

45. Srinivasu N, Ramachandran D. Determination of genotoxic impurity in atazanavir sulphate drug substance by LC-MS. J Pharm Biomed Anal 2017;132:156-8.

46. Rao LK, Devanna N, Reddy KV. Method development and validation study for quantitative determination of genotoxic impurity and its precursor in fluconazole sample by liquid chromatography-tandem mass spectrometry. Int J Pharm Pharm Sci 2016;8:84-9.

47. Jaishetty N, Palanisamy K, Maruthapillai A, Jaishetty R. Trace level quantification of the (-) 2-(2-amino-5-chlorophenyl)-4-cyclopropyl-1, 1, 1-trifluoro-3-butyn-2-ol genotoxic impurity in efavirenz drug substance and drug product using LC-MS/MS. Sci Pharm 2016;84:456-66. 
48. Harigaya K, Yamada H, Horimoto S, Nishi H, Haginaka J. Sensitive quantitation of residual phenylhydrazine in antipyrine by LC-ICP-MS with iodo derivatization. Anal Sci 2014;30:845-50.

49. Narayana M, Chandrasekhar KB, Rao BM. Quantification of genotoxic impurity 2-butyl p-toluene-sulfonate at ppm level by LC-MS/MS in naproxen drug substance. Chem Sci 2014;3:929-36.

50. Amberg A, Czich A, Thybaud V. In silico/computational assessment for the evaluation of genotoxic impurities. Pharm Ind Pract Genotoxic Impurities 2014;1425:528-53.

51. Zhu Q, Li T, Wei X, Li J, Wang W. In silico and in vitro genotoxicity evaluation of descarboxyl levofloxacin, an impurity in levofloxacin. Drug Chem Toxicol 2014;37:311-5.

52. Emerce E, Cok I, Degim IT. Determination of the impurities in drug products containing montelukast and in silico/in vitro genotoxicological assessments of sulfoxide impurity. Toxicol Lett 2015;238:90-9.
53. Guideline IH. Assessment and Control of DNA Reactive (Mutagenic) Impurities in Pharmaceuticals to Limit Potential Carcinogenic RISK M7. Geneva: International Conference on Harmonization of Technical Requirements for Registration of Pharmaceuticals for Human Use (ICH); 2014.

54. Robinson DI. Control of genotoxic impurities in active pharmaceutical ingredients: A review and perspective. Org Process Res Dev 2010;14:946-59.

55. Singh S, Handa T, Narayanam M, Sahu A, Junwal M, Shah RP. A critical review on the use of modern sophisticated hyphenated tools in the characterization of impurities and degradation products. J Pharm Biomed Anal 2012;69:148-73.

56. Jena GB, Kaul CL, Ramarao P. Genotoxicity testing, regulatory requirement for drug discovery and development: Impact of $\mathrm{ICH}$ guidelines. Indian J Pharmacol 2002;34:86-99. 